\title{
Comparison of quality parameters in conventional Pap smears made by endocervical brush smear and Ayre spatula
}

\author{
Arshiya Bose ${ }^{1}$, Mousumi Acharya ${ }^{2}$, Prita Pradhan $^{1 *}$, Kanakalata Dash ${ }^{1}$, Urmila Senapati $^{1}$
}

${ }^{1}$ Department of Pathology, Kalinga Institute of Medical Sciences, Bhubaneswar, Odisha, India

${ }^{2}$ Department of Obstetrics and Gynaecology, Kalinga Institute of Medical Sciences, Bhubaneswar, Odisha, India

Received: 13 November 2020

Accepted: 18 November 2020

*Correspondence:

Dr. Prita Pradhan,

E-mail: prita88@gmail.com

Copyright: (c) the author(s), publisher and licensee Medip Academy. This is an open-access article distributed under the terms of the Creative Commons Attribution Non-Commercial License, which permits unrestricted non-commercial use, distribution, and reproduction in any medium, provided the original work is properly cited.

\section{ABSTRACT}

Background: Cervical Pap smear is a form of exfoliative cytology and has been widely accepted as a screening tool for cervical cancers. Among the various devices for collecting samples from cervix, wooden Ayre spatula and cytobrush are used commonly. Ayre spatula collects cells from the ectocervix whereas cytobrush from the transformation zone (TZ) and this study compares both techniques.

Methods: A retrospective study was done by comparing two conventional Pap smears from all consecutive samples received in the cytopathology section of department of pathology $(n=388)$; one with Ayre spatula and one with endocervical brush. They were compared for quality parameters like spreading and staining of cells, morphologic preservation, presence of $\mathrm{TZ}$ component, degree of inflammation, presence of infection and predominant cell population. Appropriate statistical analysis was performed.

Results: The smears made out of Ayre spatula showed better spreading $(p \leq 0.00001)$ and staining $(p=0.00022)$ as compared with those made using endocervical brush. However, the morphological preservation was equally comparable in both. The TZ component was significantly higher in the endocervical brush smear $(\mathrm{p}=0.00001)$. Inflammation was comparable in both $(\mathrm{p}=0.1916)$. Infection was detected more in ectocervical smears $(\mathrm{p}=0.00001)$. The cytobrush smears showed a significantly higher detection rate of endocervical cells $(\mathrm{p} \leq 0.00001)$.

Conclusions: Based on our study, we conclude that the use of both Ayre spatula and endocervical brush together ensures higher efficiency than using a single method.

Keywords: Pap smear, Quality parameters, Ayre spatula, Endocervical brush

\section{INTRODUCTION}

The Pap smear or Papanicolaou test, is a form of exfoliative cytology wherein microscopic examination of cells taken from the cervix is performed. ${ }^{1}$ It was designed by Dr George Nicholas Papanicolaou (1883-1962) who was an American anatomist of Greek origin during the 1920s. ${ }^{1}$ It is a simple, quick and non-invasive method that has almost revolutionized early detection of cancer as a screening tool for cervical cancer. The application of screening programmes for cervical cancer has achieved a reduction of $80 \%$ in incidence and mortality. ${ }^{2}$ Pap smears from junction between the ectocervix and the endocervical canal, also known as the transformation zone (TZ) of the cervix, can be used for early identification of cervical epithelial cell abnormalities in the stage of intra-epithelial neoplasm itself. This TZ is highly susceptible to Human papillomavirus (HPV) infection, which is known for its carcinogenicity.

Pap stain provides distinctive morphological advantage over other stains as it gives a well stained nuclear chromatin, differential counterstaining of the cytoplasm and retains the cytoplasmic transparency. ${ }^{3}$ Staining can be achieved by progressive or regressive method. ${ }^{4}$ Conventional Pap tests have a moderate sensitivity of 30- 
$80 \%$ and high specificity of $86-100 \%$. In conventional smears, specimen is collected using either an Ayre spatula or an endocervical brush or both. There is conflicting evidence on the advantages and disadvantages of both. So, this study was taken up to compare the quality of smears of the endocervical brush and ectocervical Ayre spatula.

\section{METHODS}

This was a retrospective observational study done in the cytology section, department of pathology, from September 2018 to July 2020 over a period of two years. The study population was defined as all consecutive Pap smear samples received in the cytopathology section of department of pathology, during the study period, for which two conventional Pap smears were collected; one with Ayre spatula from the ectocervix and one was an endocervical brush smear. They were placed in a Coplin jar containing 95\% ethanol in fixative (Figure 1). They were labelled and sent to the laboratory. All the smears received during the study period were stained as per the standard operating procedure of the laboratory for Papanicolaou stain. Reagents used in Pap stain were Harris haematoxylin for nuclear staining, orange G-6 (OG-6) for cytoplasmic counterstain and eosin azure (EA) which is a polychromatic stain made of 3 dyes, eosin $\mathrm{Y}$ for mature squamous cells, light green SF for metabolically active cells and Bismarck brown Y. Various concentrations of alcohol (ranging from 70 to $95 \%$ ) were used for hydration and dehydration. The smears were reviewed blinded by cytopathologists, according to the standard system of the 2014 Bethesda system for reporting cervical cytology.

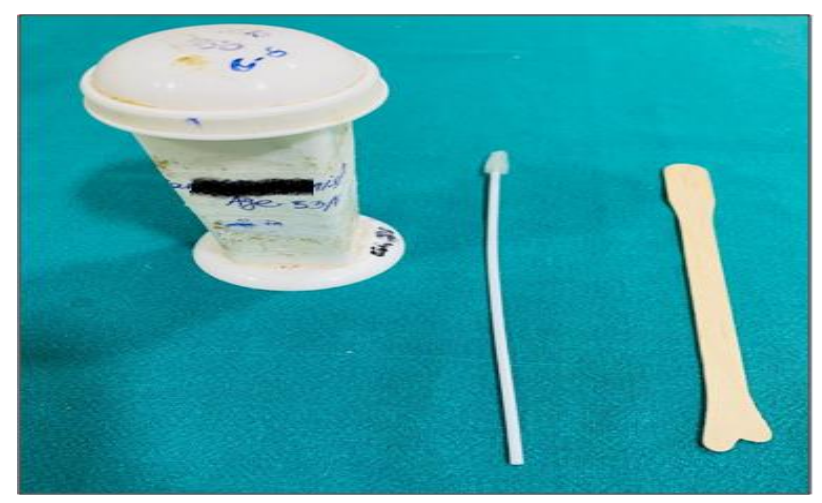

Figure 1: A Coplin jar containing $95 \%$ ethanol as fixative, endocervical brush (red arrow) and Ayre wooden spatula. Two labelled smears were collected using both instruments and received in the jar.

The staining of the smears was categorised arbitrarily as poor (-), well (1+), moderate $(2+)$ and excellent $(3+)$ depending on the intensity and differentiation. The spreading was evaluated based on whether the cells were confined to one area in the smear (-), few patchy areas with clumping $(1+)$, multiple patches with overlapping (2+) or uniformly distributed with minimal overlapping
(3+). Morphologic preservation was classified into three categories poor (-), moderate (1+) and well (2+) based on the degree of clarity of the nuclear and cytoplasmic details as well as cellular distortion. The cellular composition was studied in 50 low power fields and the overall most predominant cell type was identified. Inflammation was semi-quantitatively graded as occasional $(\langle 25 \% ; 1+)$, mild $(25-50 \% ; 2+)$, moderate $(50$ $75 \%, 3+)$ and dense $(>75 ; 4+)$. This was estimated after compiling both the endo-and ectocervical smears. Background haemorrhagic, mucoid or clean was noted.

Analysis of cytomorphologic data was performed to check the quality of technical parameters in the evaluation of Pap smears by two independent pathologists. All the statistical analysis was carried out using Wilcoxon log rank test using (C2020 Jeremy Stangroom. A $\mathrm{p} \leq 0.05$ was considered significant.

\section{RESULTS}

During the study period a total of 776 pap smears were studied. Overall age range of all participants was from 20 to 49 years with a mean age of 33.1 years. Majority of the smears were satisfactory in both categories ( 99.74\%). The fixation was found to be optimal in all smears.

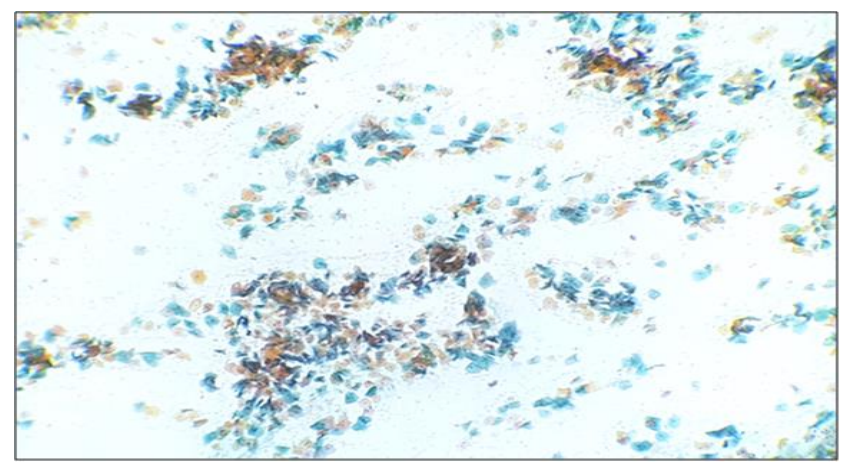

Figure 2: Pap smear from ectocervix taken from Ayre spatula of a satisfactory well-spread, well-stained smear with well-preserved morphology (Pap, 400X).

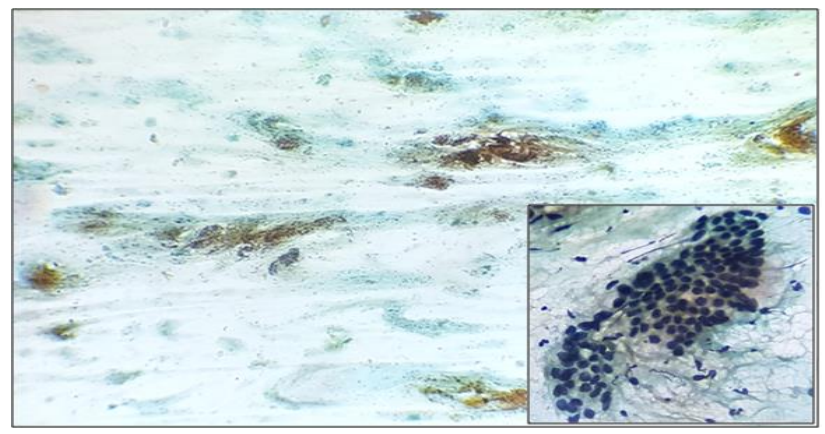

Figure 3: Pap smear from endocervix taken with endocervical brush of a poor spreading, well-stained smear with well-preserved morphology; inset endocervical cells (Pap, 400X). 


\section{Spreading}

The smears prepared by Ayre spatula showed better spreading in 306 slides (78.9\%) as compared to smears prepared by endocervical brush in 246 slides (63.4\%).

\section{Staining}

The smears prepared by Ayre's spatula showed better staining in 292 slides $(75.6 \%)$ as compared to those prepared by endocervical brush in 256 slides (66\%).

\section{Morphology}

Morphological preservation was comparable in smears prepared by both Ayre spatula (340 slides, $87.7 \%$ ) and endocervical brush (334 slides, $86.1 \%$ ).

\section{Transformation zone component}

The rate of obtaining TZ component was significantly higher in the endocervical brush smear (325 slides, 83.8\%) than Ayer's spatula (162 slides, 41.8\%).

The technical parameters of the ectocervical and endocervical smears were statistically compared and are summarised in (Table 1).

The smears made out of Ayre's spatula showed better spreading and staining as compared with those made using endocervical brush. However, morphological preservation was equally comparable in both. The TZ component was higher in endocervical brush smear.

Table 1: Quality parameters in the Pap smears made by Ayre spatula and endocervical brush ( $\mathrm{n}=388$ ).

\begin{tabular}{|c|c|c|c|c|}
\hline Parameter & Category & $\begin{array}{l}\text { Ayre spatula } \\
(\mathrm{n}=388), \text { no }(\%)\end{array}$ & $\begin{array}{l}\text { ECC brush smear } \\
(\mathrm{n}=388), \text { no }(\%)\end{array}$ & $\begin{array}{l}\text { P value } \\
\text { (Wilcoxon) }\end{array}$ \\
\hline Well spread & $\begin{array}{l}\text { Poor }(-) \\
\text { Well }(1+) \\
\text { Moderate }(2+) \\
\text { Excellent }(3+)\end{array}$ & $\begin{array}{l}18(4.6) \\
64(16.5) \\
99(25.6) \\
207(53.3)\end{array}$ & $\begin{array}{l}31(7.9) \\
111(28.7) \\
139(35.9) \\
107(27.5)\end{array}$ & $\begin{array}{l}<0.00001 \\
\mathrm{z} \text { is }-6.7948\end{array}$ \\
\hline Well stained & $\begin{array}{l}\text { Poor }(-) \\
\text { Well }(1+) \\
\text { Moderate }(2+) \\
\text { Excellent }(3+)\end{array}$ & $\begin{array}{l}27(7.0) \\
69(17.4) \\
111(28.8) \\
181(46.8)\end{array}$ & $\begin{array}{l}28(7.2) \\
104(26.8) \\
123(31.7) \\
133(34.3)\end{array}$ & $\begin{array}{l}0.00022 \\
\mathrm{z} \text { is }-3.7043\end{array}$ \\
\hline Morphology & $\begin{array}{l}\text { Poor (-) } \\
\text { Moderate (1+) } \\
\text { Well (2+) }\end{array}$ & $\begin{array}{l}48(12.3) \\
142(36.5) \\
198(51.2)\end{array}$ & $\begin{array}{l}54(13.9) \\
193(49.7) \\
141(36.4)\end{array}$ & $\begin{array}{l}0.00016 \\
\mathrm{z} \text { is }-3.7949\end{array}$ \\
\hline $\begin{array}{l}\text { Transformation } \\
\text { zone }\end{array}$ & $\begin{array}{l}\text { ECC cells } \\
\text { MP cells } \\
\text { Both } \\
\text { Absent }\end{array}$ & $\begin{array}{l}134(34.6) \\
17(4.4) \\
11(2.8) \\
226(58.2)\end{array}$ & $\begin{array}{l}200(51.6) \\
40(10.3) \\
85(21.9) \\
63(16.2)\end{array}$ & $\begin{array}{l}0.00001 \\
\mathrm{z} \text { is }-7.7504\end{array}$ \\
\hline
\end{tabular}

Abbreviations: ECC-Endocervical; MP-Metaplastic

\section{Degree of inflammation}

Difference between the degree of inflammation both types of smears was not significant and was comparable in both ( $\mathrm{p}$ value $0.8493, \mathrm{Z}$ score $=-0.1916$ )

\section{Presence and absence of infection}

The distribution of infection among ectocervical and endocervical smears is given in Table 2 .

The difference in detection of infection was significantly higher in the ectocervical smears $(\mathrm{p}<0.00001, \mathrm{z}-4.3925$.

\section{Cellular composition}

It showed statistically significant difference in both groups with high detection of endocervical cells in Cytobrush smears ( $\mathrm{p}<0.00001, \mathrm{z}$ score 4.3925).
Table 2: Distribution of infection among ectocervical and endocervical smears.

\begin{tabular}{|llll|}
\multirow{2}{*}{ Infection } & \multicolumn{2}{l}{ No $(\%), \mathbf{n}=\mathbf{2 0 0}$} & \multirow{2}{*}{ P value } \\
\cline { 1 - 4 } & Ectocervix & Endocervix & \\
\hline Present & $55(27.5)$ & $37(18.5)$ & $<0.00001$ \\
\hline Absent & $145(72.5)$ & $163(81.5)$ & \\
\hline
\end{tabular}

Table 3: Distribution of the cellular composition in endo and ectocervical smears.

\begin{tabular}{|lll|}
$\begin{array}{l}\text { Predominant cell } \\
\text { type }\end{array}$ & $\begin{array}{l}\text { Ectocervical } \\
\text { smear }\end{array}$ & $\begin{array}{l}\text { Endocervical } \\
\text { smear }\end{array}$ \\
\hline Superficial cell & 289 & 206 \\
\hline Intermediate cell & 82 & 67 \\
\hline Endocervical cell & 17 & 115 \\
\hline
\end{tabular}

\section{DISCUSSION}

Exfoliative cytology is the study of cells that are shed off or scraped from mucosal surfaces. Pap smear is a form of 
exfoliative cytology wherein cervical cells are scraped and examined for cellular changes, often starting at the transformation zone. It is named after Dr. George Nicholas Papanicolaou, an American anatomist of Greek origin who collected and studied cells from vagina of guinea pigs. ${ }^{5}$ Pap smear is strongly advocated as a screening tool for cervical cancers. There are various equipment's for collection of Pap smears which include cotton tip applicator, wooden spatula, plastic spatula, endocervical brush and Cervex-brush. According to TBS, 2014 Pap smear sampling is considered adequate if there are 8000 to 12000 well-preserved, well-visualised squamous epithelial cells in the smear. ${ }^{6}$ However, presence of $\mathrm{TZ}$ is considered as an important quality indicator since metaplasia and cervical carcinoma begin from the $\mathrm{TZ}^{7}$ Therefore, the ultimate aim of sample collection should be to fulfil both the adequacy criteria and the quality indicator. In our setting, combination of Ayre spatula, a type of wooden spatula and endocervical brush is being used.

As we used two methods of smear preparation, in our study, we compared the quality parameters between the endocervical brush smear and Ayre spatula. Spreading and staining of squamous epithelial cells were better in ectocervical smear collected with Ayre spatula, although the morphological preservation was equivocal in both types of smears. Likely because the endocervical smear preparation inherently involves insertion of the brush into the endocervical canal, rotated and smeared, the endocervical brush showed higher rate of obtaining cells from the TZ. Our findings were similar to previous studies and meta-analysis which showed that a 'cytobrush' accompanied with 'spatula' is the most effective Pap smear device to detect cervical abnormalities. $^{8,9}$

In our experience the endocervical smears showed extensive mucoid background which often distorts the cellular morphology. This causes cell distortion and entrapment due to which clumped cells with poor spreading occurs leading to poor stain penetration is seen. Frequently caking of the mucoid background was seen. A study by Soleimani et al showed that the cytomorphological preservation with the use of spatula and cytobrush was comparable and neither of the methods caused excessive bleeding or pain. ${ }^{10}$ In our study, morphological preservation was comparable in smears prepared by both Ayre spatula (340 slides, 87.7\%) and endocervical brush (334 slides, 86.1\%) indicating their complementary role and emphasising that using both methods is more useful. Many studies have shown that smears with no endocervical cells are more likely to carry false negative results for cervical cancer. ${ }^{11}$ Therefore, in order to minimize the number of false negative results, slides should contain adequate number of squamous cells and endocervical cells. ${ }^{12,13}$ In a study by O'Mahony et al, the authors state that cytobrush will ensure lesser need for repeat sampling as it is significantly more efficacious than the Ayre spatula to obtain adequate cervical smears. ${ }^{14}$ Another study by Luzzatto et al showed endocervical brush to be more efficacious than Ayre's spatula in obtaining endocervical cells. ${ }^{15}$ Similar to our findings, they have also said that the use of brush smears is more effective at picking up the TZ. Cellular composition-wise the endocervical cells were most predominant in the brush smears. Here we need to emphasize, that on one hand both squamous cells and TZ components are essential, on the other hand the quality of the smears and morphological preservation should also be optimal. The former in our experience was better with brush while the latter with spatula. So, we can recommend that the use of both Ayre spatula and endocervical brush together during cervical screening programmes can maximise the abnormality detection rates. However, as O'Mahony et al have put it, a single device can be advised in busy out patient department (OPDs) as there is a chance of missing any pathology in the ectocervix. ${ }^{14}$ Also, the use of only one device to be an effective screening tool requires many years of experience in order to ensure that the device is used effectively.

Th detection of infections was found to be higher with the use of spatula in our experience than with brush smears. Based on our study, we conclude that the use of both Ayre spatula and endocervical brush together ensures higher efficiency than using a single method. This is because the smears collected by Ayre spatula shows higher rates of obtaining adequate smears, thus, minimizing the need to perform repeat tests. Also, it offers better spreading and staining of the cells. The smears prepared by the endocervical brush shows higher rates of obtaining $\mathrm{TZ}$ cells which is essential for detecting early cervical cancers thus making Pap smears an important screening tool for the same. So, use of both types of smears can help in circumventing the limitations posed by each of the individual techniques.

\section{CONCLUSION}

In conclusion, although the chances of obtaining TZ component is higher with cytobrush, use of Ayre spatula cannot be overlooked as it provides adequate number of squamous cells as per the satisfactory criteria for Pap smears according to TBS, 2014. Also, spreading, staining and presence of infections are better visualised in ectocervical smear. Therefore, it negates the need for repeat smear. Hence, we recommend use of both Ayre spatula and cytobrush for optimum results.

Funding: No funding sources

Conflict of interest: None declared

Ethical approval: Not required

\section{REFERENCES}

1. Tan SY, Tatsumura Y. George Papanicolaou (18831962): Discoverer of the Pap smear. Singapore Med J. 2015;56:586-7.

2. Nieminen $\mathrm{P}$, Kallio $\mathrm{M}$, Anttila A, Hakama M. Organised vs. spontaneous Pap-smear screening for 
cervical cancer: A case-control study. Int J Cancer. 1999;83:55-8.

3. Mokobi F. Papanicolaou Staining (Pap stain) for Pap Smear/Pap Test. Online Microbiol and Biol. 2020;2:2-10

4. Soost HJ, Falter EW, Otto K. Comparison of two Papanicolaou staining procedures for automated prescreening. Anal Quant Cytol. 1979;1:37-42.

5. Haider G, Parveen Z, Anjum F, Munir A. Pap smear, an important screening tool to detect precancerous stage of carcinoma of cervix. J Ayub Med Coll Abbottabad. 2013;25:26-7.

6. Nayar R, Wilbur DC. The Pap Test and Bethesda 2014. ACY. 2015;59:121-32.

7. Solomon D, Nayar R. The Bethesda System for Reporting Cervical Cytology: Definitions, Criteria, and Explanatory Notes. Springer Sci Business Media. 2004;220.

8. Bauman BJ. Use of a cervical brush for Papanicolaou smear collection. A meta-analysis. J Nurse Midwifery. 1993;38:267-75.

9. Valenzuela P, Martinez P, Santana A, Garrido N, Cano A, Arnanz F. Comparison of cervical smears secured with different instruments. Acta Obstet Gynecol Scand. 2001;80:262-6.

10. Soleimani M, Abdali K, Khajehei M, Tabatabaee H, Komar P, Riaz Montazer N. Comparison of pap smear quality with anatomical spatula method and the common method (spatula-cytobrush): a single blind clinical trial. Iran J Cancer Prev. 2012;5(1):338.

11. Buntinx F, Brouwers M. Relation between sampling device and detection of abnormality in cervical smears: a meta-analysis of randomised and quasirandomised studies. BMJ. 1996;313:1285-90.

12. Rammou-Kinia R, Anagnostopoulou I, Gomousa M. Comparison of spatula and nonspatula methods for cervical sampling. Acta Cytol. 1991;35:69-75.

13. Neinstein LS, Church J, Akiyoshi T. Comparison of cytobrush with Cervex-Brush for endocervical cytologic sampling. J Adolesc Health. 1992;13:5203.

14. O'Mahony D. A comparison of cervical smear adequacy using either the cytobrush or the Ayre spatula: a practice audit. SA Fam Pract. 2006;48:15.

15. Luzzatto R, Boon ME. Contribution of the Endocervical Cytobrush Sample to the Diagnosis of Cervical Lesions. ACY. 1996;40:1143-7.

Cite this article as: Bose A, Acharya M, Pradhan P, Dash K, Senapati U. Comparison of quality parameters in conventional Pap smears made by endocervical brush smear and Ayre spatula. Int J Reprod Contracept Obstet Gynecol 2020;9:4907-11. 